\title{
CULTURAL HERITAGE BOUNDARIES AND TYPOLOGY OF PEACE LANDSCAPE
}

\author{
Alon Gelbman \\ Department of Tourism and \\ Hotel Management, \\ Kinneret College on the Sea of Galilee, \\ Israel
}

\begin{abstract}
:
Tourism has been mentioned as a social force that can contribute and promote international understanding, cooperation and global goodwill for establishing and maintaining world peace. Heritage development suggests that tourism efforts can help to ease tensions and promote cross-cultural dialogue and reconciliation. Geopolitical border areas are dynamic, and their reality can change over time. Similarly, their heritage can also develop which in many cases revolves around social and cultural differences and contrasts with the other side of the border. The main aim of this paper is to examine and analyse the methods through which different types of geopolitical borderland heritage are expressed as peace tourism attractions in diverse international case studies. The three types and case studies discussed in this paper are: A. Closed conflict borderland: the Dorasan train station on the border separating South Korea and North Korea; B. Semi-open borderland and peace: The 'Green Belt' crossing Europe along the former 'Iron Curtain' between Western and Eastern European countries; C. Heritage and peace in supranational borderlands: The 'For Europe' Garden on the border triangle of Luxembourg, Belgium and Germany. The methodology selected is based on the naturalistic-qualitative approach of landscape interpretation by significance analysis of the three types of geopolitical borderland heritage in diverse tourism and peace attractions around the world.
\end{abstract}

Keywords:

International Boundaries; Heritage Tourism; Geopolitical Conflict; Peace; Landscape

\section{INTRODUCTION}

Geopolitical border areas are dynamic and their reality can change over time. Similarly, their heritage can also develop which in many cases revolves around social and cultural differences and contrasts with the other side of the border (Timothy 2001). Tourism has been mentioned as a social force that can contribute and promote international understanding, cooperation and global goodwill for establishing and maintaining world peace (D’Amore 1988; Litvin 1998; Kim et al. 2007). Heritage development suggests that tourism efforts can help to ease tensions and promote cross-cultural dialogue and reconciliation, particularly when such development is community-based or 'bottom-up' (Giblin 2014). For example, border tourism attractions often present the story of local heritage and historical events as well as
Correspondence:

Alon Gelbman

e-mail:

alongelbman@gmail.com 
the natural environment, which can generate interest among visitors (Zeppel and Hall 1992; Timothy 2001). In this way, tourists, along with the host communities, can be engaged in the complex - and often contested - symbolism represented by these sites (Gelbman 2008; Gelbman and Timothy 2010). While the relationship between tourism development and peace is actively debated in the literature, this chapter presents several case studies that suggest tourism development in border regions can provide new opportunities for using heritage as a reconstructive tool.

The varying effects of cross-border openness on tourism development can be described as a process of change along a time axis (Timothy 2001; Gelbman and Timothy 2010). A closed and fortified border means an absence of tourism development and little, if any, tourism access to the border area for security and political reasons. At times, one-sided border attractions develop, allowing tourists of one country to overlook the 'other side'. With geopolitical changes, the border may undergo a transformation and become an open boundary. The boundary line can then become a tourist attraction that focuses mainly on the history and heritage of the place, but also offers the possibility of developing more varied tourism products in the formerly closed border areas in which it develops (Gelbman and Timothy 2010).

The main aim of this paper is to examine and analyse the methods through which different types of geopolitical borderland heritage are expressed as peace tourism attractions in diverse international case studies. The three types and case studies discussed in this paper are:

A. Closed conflict borderland: the Dorasan train station on the border separating South Korea and North Korea; B. Semi-open borderland and peace: The 'Green Belt' crossing Europe along the former 'Iron Curtain' between Western and Eastern European countries; C. Heritage and peace in supranational borderlands: The 'For Europe' Garden on the border triangle of Luxembourg, Belgium and Germany. The methodology selected is based on the naturalistic-qualitative approach of landscape interpretation (Tracy, 2012) by significance analysis of the three types of geopolitical borderland heritage (Matznetter 1979; Timothy 1999; Gelbman 2008) in diverse tourism and peace attractions around the world. The tourism developments in the selected case studies are based in part on the extent of trans-border openness (in the past and present).

\section{RESULTS \& DISCUSSION}

\section{Heritage and Peace at a Hostile Closed Borderland (A)}

The Dorasan train station is located near the borders of the dangerous Demilitarised Zone (DMZ) between South Korea and North Korea (Kim, Prideaux and Prideaux, 2007). Dorasan Station opened in 2002 and is, depending on how one looks at it, either the last railway stops in South Korea or the first stop in North Korea from the south. Although the tracks are connected, the Communist regime to the North does not allow trains to pass through, so the space is a tourism attraction with the South Korean soldiers, and the travelers wander around the train station, taking in the impressive artwork and advertisements that adorn the walls (see figure 1). The dozens of chairs in the expansive lobby look brand new, the floor is shiny, and a screen provides information to visitors. Travelers look at their reflections in the bulletproof glass of the façade. A man behind the ticket counter is ready to sell boarding passes to anyone passing through the turnstiles before heading outside to its platforms. This situation matches the tourist experience when visiting one side of a closed and fortified border (Matznetter 1979; Timothy 1999) and the duality model of Gelbman (2008): fear of the present threatening reality but also hope for a better reality in the future. However, tourists would not know it from looking at the immaculately maintained station, which serves as a beacon of hope for reunification on the Korean peninsula. 
Figure 1. Tourists are visiting the Dorasan train station attraction in South Korea

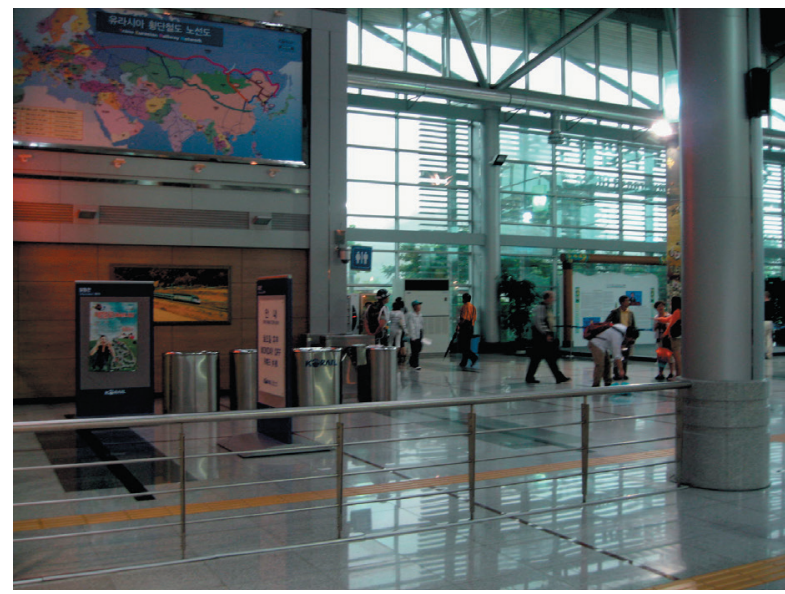

(Photo: the author)

A sign in the lobby reads: 'Not the last station from the South, but the first station toward the North'. In 2000, representatives from both the South and North Korean governments agreed to link the two countries on the Gyeongui Railroad Line. The mines and barbed wire were removed, and Dorasan Station opened on the South Korean side about two years later. The station roof features the traditional clasped hands, a largely symbolic offering of hope for peace and eventual reconciliation between the two foes. On 14 June 2003 the tracks were connected at the Military Demarcation Line in the DMZ. For a short time, limited freight flowed back and forth from the Kaesong Industrial Complex, just on the North Korean side of the border where female North Koreans are allowed to work for South Korean companies in isolation from the rest of the populace. However, recurring tensions and posturing brought a quick end to these activities and now the station is a dead end. The surrounding warehouses and customs buildings are unused and appear to be still wet with fresh paint - beacons amid bleak Korean winter and remote surroundings (Burke 2012).

The South Korean soldiers at Dorasan are friendly and some pose for photos with smiling tourists. For less than a dollar, visitors buy tickets as a souvenir and have them stamped for embarkation. Tour guides usher visitors outside to the paved platform and to a billboard commemorating the place where former US President George W Bush gave a speech during his term in office about the importance of the station as an olive branch. This is next to a sign giving the distances to Seoul in one direction $(56 \mathrm{~km})$, and to Pyongyang $(205 \mathrm{~km})$ in the other. The tracks seem to stretch endlessly in both directions, into a no man's land (ibid).

An eerie quiet and sense of unease hangs thick in the air even though busloads of tourists are ferried in and out almost each and every day. The abandoned buildings nearby and the absence of trains is emotionally stirring. The best way to visit the station is to book a tour before arriving in Seoul (ibid). In these ways, the station perfectly illustrates the divide between North and South. The station is an invitation to a world community that will surely spell the end of North Korea's regime. So, for now the invitation is open and the trains do not run but the station and surrounding buildings are maintained and sit idly, waiting for that day to come.

\section{Heritage and Peace at a Semi-Open Borderland (B)}

Several European nature organizations and NGOs developed the idea and the development underlying the European Green Belt (since the beginning of the 2000s); crossing Europe along the former 'Iron Curtain' between Western and Eastern Europe is to create the backbone of an ecological network, running from the Barents to the Black Sea that is a global symbol for trans-boundary cooperation in nature conservation, geopolitical peace and sustainable development. This initiative spans the historic course of the Iron Curtain in Europe and its analogous extension in Fennoscandia, serving as a reminder of the barriers that separated Europeans in the past and, in some instances, still do so in the present. The Green Belt has the potential to 
contribute to the implementation of different international agreements and legislations. Overall, the Green Belt offers an exceptional tool to support Europe's natural and historical heritage. This can open new sources of income and increase opportunities for the socio-economic development of local communities (see Figure 2). The Green Belt is also intended to better harmonies human activity with the natural environment and foster trans-boundary cooperation between people, regions and neighboring countries. On this basis the Green Belt can enhance cooperation between the old and new EU member states, across the new EU borders or the still sensitive borders in south-eastern Europe. It provides a special opportunity to highlight the importance of ecological networks in truly linking people and nature (Terry et al. 2006).

Figure 2. Cross border cooperation along the 'Green Belt'

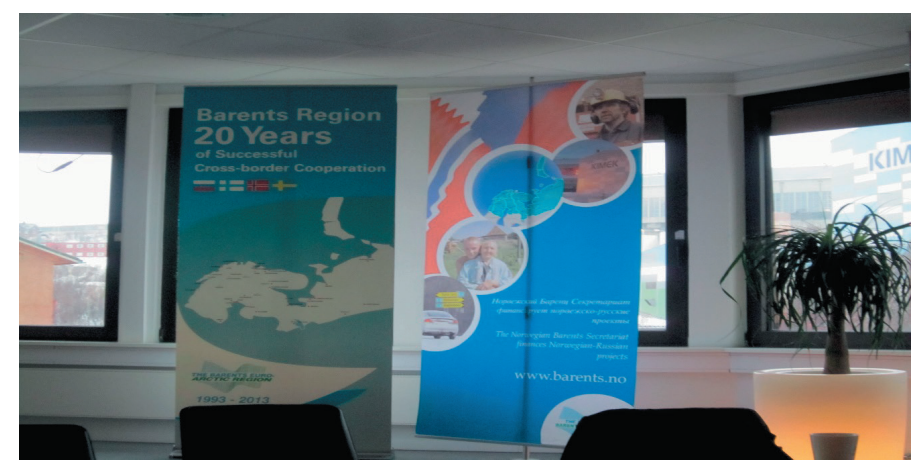

(Photo: the author)

Because of the expansion and strengthening of the European Union (EU), the current trend is towards nurturing trans-frontier parks in these areas. One of the interesting examples of tourism development along the Green Belt is the Friendship Park, announced as part of the signing of the 1989 agreement between the governments of Russia and Finland. Their vision - 'nature without borders' - set out shared cooperative management of the park which spreads over both sides of the border. The cooperation is to be in matters of scientific research, nature protection and the protection of wild forest reindeer.

In this Friendship Park, as well as in other parts of the Green Belt which crosses 23 countries throughout Europe, cooperative management helps to implement the vision of conservation of the ecological network, running from the Barents Sea to the Black Sea, and is a global symbol for trans-boundary cooperation in nature conservation and sustainable development (Terry et al. 2006). It is a good example of better harmony between human activities and the natural environment. Tourists are invited to experience the Green Belt, enjoy nature and learn about the heritage of the border, which was dark in the past but has now become another symbol of the transformation of the former Iron Curtain border from one of hostility and separation to one of cooperation and friendship. While the Green Belt and the Friendship Park that forms part of it symbolize the transformation of border areas in the age of globalization, the For Europe Garden is more an expression of, and the integration of, border areas (Timothy 1999) and the removal of borders, as is happening in Europe in this age of the European Union.

\section{Heritage and Peace of Supranational Borderlands (C)}

The 'For Europe' peace garden on the border triangle of Luxembourg, Belgium and Germany, established by the EU including the For-Europe monument (see Figure 3), is a significant symbol of the process of unification and supranationalism in Europe today. While the Green Belt and the Friendship Park that forms part of it symbolize the transformation of border areas in the age of globalization, the For Europe Garden is more an expression of, and the integration of, border areas (Timothy 1999) and the removal of borders, as is happening in Europe in this age of the European Union. The garden invites visitors to an open space museum which tells the story of the beginning of the EU with six countries and the extension of this process during 
recent decades. Visitors can feel the lack of physical obstacles at the many border crossings between the three European countries on which the garden stands. They can cross the 'Peace Bridge' above a waterway which is actually the formal border between Belgium and Luxembourg and they can learn about the development of the EU through explanations and pictures on display in the open museum.

Figure 3. The monument in the 'For Europe' peace garden

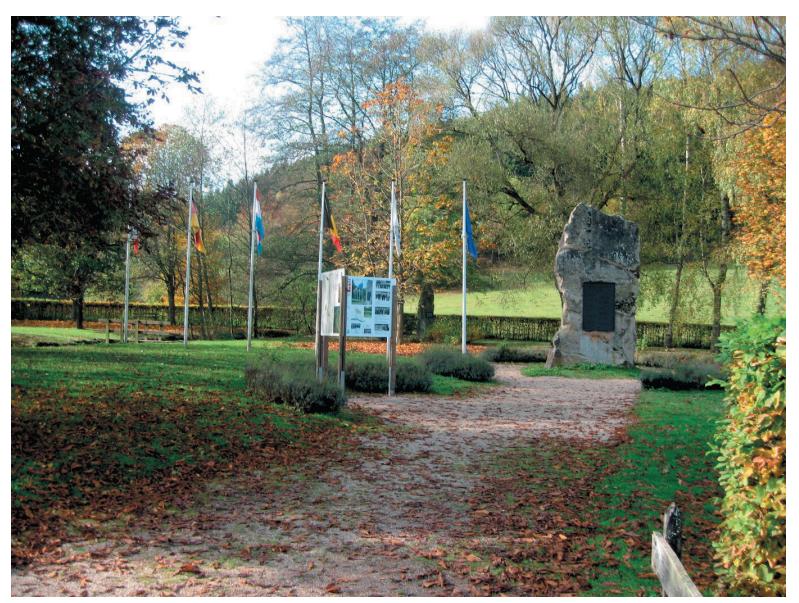

(Photo: the author)

\section{CONCLUSIONS}

Geopolitical border areas are dynamic, and their reality can change over time. Similarly, their heritage can also develop which in many cases revolves around social and cultural differences and contrasts with the other side of the border (Timothy 2001). From analysis of case studies it can be seen that border tourism attractions combine the heritage of the past with the connection of the sites to different way of peace elements. This develops depends on the geopolitical changes, as do the nature and types of attractions offered to the visitors. The case studies presented here demonstrate different types of sites that may be offered: from attractions that highlight areas of conflict with a closed and fortified border (the Dorasan Station in the DMZ between North and South Korea); to open or semi open peace borders that symbolize a new reality of peace in contrast to the conflicted past (the Green Belt in Europe); and attractions of supranational peace border tourism (For Europe Garden), a symbol of the new age of globalization which encourages the removal of physical and administrative borders and replaces them with integrative borders (Timothy 1999).

While peace attractions in border areas of conflict may deal with the message of hope for a better future (Gelbman 2008), attractions of supranational peace tourism are characterized by parks and gardens, symbols and messages of goodwill and optimal international relations with long-lasting peace in an age of globalization and the removal of physical geopolitical obstacles. It appears that heritage of the border areas, which often express socio-economic and cultural contrasts and differences on the two sides of a border, are the most suitable place for approaching and symbolizing processes of peace and cooperation through the tourist sites and attractions around them.

Borderlander communities are societies that once had to bear the heritage of suffering created by border closings in the past and the dark geopolitical reality that prevailed on both sides of the border. Examples are the communities that lived on both sides of the former Iron Curtain separating Communist Eastern Europe from democratic Western Europe. Today, they may be the beneficiaries of the process of border openings and the removal of physical, social and political barriers along the border. Borderlanders, together with tourists, can sense the experience of extensive tourism development along the length of the Green Belt, a proud symbol of the community and society that has been transformed from a dark heritage steeped in war to a tangible and intangible heritage of nature, culture and sustainable peace. 


\section{REFERENCES}

Burke, M M. (2012). South Korea: Dorasan train station in DMZ still waiting for a connection. Management, 28, 556-569.

D’Amore, L. (1988). Tourism: The World's Peace Industry. Journal of Travel

Research, 27, 35-40.

Gelbman, A. (2008). Border Tourism in Israel: Conflict, Fear, Peace and Hope. Tourism Geographies, 10, 193-213.

Gelbman, A, \& Timothy, D J. (2010). From Hostile Boundaries to Tourist Attractions. Current Issues in Tourism, 13(3), 239-259.

Giblin, J D. (2014). Post-conflict heritage: symbolic healing and cultural renewal. International Journal of Heritage Studies, 20(5), 500-518. DOI:10.1080/13527258.2013.772912

Kim, S S, Prideaux, B., \& Prideaux, J. (2007). Using Tourism to Promote Peace on

the Korean Peninsula. Annals of Tourism Research, 34, 291-309.

Litvin, S. (1998). Tourism: The World's Peace Industry. Journal of Travel Research, 37, 63-66.

Matznetter, J. (1979). Border and tourism: Fundamental relations, in Tourism and Borders: Proceedings of the Meeting of the IGU Working Group - Geography of Tourism and Recreation (eds G Gruber, H Lamping, W Lutz, J Matznetter, and K Vorlaufer), Institut für Wirtschafts- und Sozialgeographic der Johann Wolfgang Goethe-Universität, Frankfurt, 61-73.

Terry, A, Ullrich, K, and Riecken, U. (2006). The Green Belt of Europe: From Vision to Reality. Gland : IUCN.

Timothy, D J. (1999). Cross-border partnership in tourism resource management: International parks along the US-Canada border. Journal of Sustainable Tourism 7(3-4), 182-205.

Timothy, D J, 2001 Tourism and Political Boundaries. London: Routledge.

Tracy, S. J. (2012). Qualitative research methods: Collecting evidence, crafting analysis, communicating impact. John Wiley \& Sons.

Zeppel, H., \& Hall, C. M. (1992). Arts of Heritage Tourism. In Special Interests Tourism (eds B Weiler and C M Hall), 47-68. London: Belhaven Press. 